\title{
FORMULASI BAGIAN WARIS BAGI LAKI-LAKI DAN PEREMPUAN PERSPEKTIF MUFASSIR
}

\author{
Mohamad Rana, Akhmad Shodikin \\ Fakultas Syariah dan Ekonomi Islam \\ Institut Agama Islam Negeri Syekh Nurjati Cirebon \\ Email: mohamadrana85@yahoo.com, shodikin73@gmail.com
}

\begin{abstract}
ABSTRAK
Penelitian ini merupakan satu kajian mengenai formulasi bagian waris bagi laki-laki dan perempuan perspektif mufassir. Penelitian ini bertujuan untuk mengetahui pandangan dan landasan argumentasi mufassir terkait jumlah bagian waris bagi laki-laki yang lebih besar dibandingkan perempuan. Dalam mengumpulkan data, kajian ini menggunakan kajian kepustakaan (library research). Hasil kajian ini menegaskan bahwa ketetapan pembagian warisan bagi laki-laki dan perempuan dengan ketentuan 2:1 merupakan bentuk pengangkatan martabat perempuan yang sebelum Islam datang berada pada posisi termarginalkan. Disamping itu, ketentuan tersebut merupakan bentuk keadilan universal Islam baik kepada laki-laki dan perempuan yang memiliki beban tanggung jawab yang berbedam baik secara teologi, sosial, dan ekonomi.
\end{abstract}

Kata Kunci: Formulasi, Waris, dan Mufassir

\begin{abstract}
This research is a study of the formulation of the inheritance section for men and women commentator perspective. This study aims to determine the views and basis for commentator's argument related to the number of heirs for men which is greater than women. In collecting data, this study uses a library research (library research). The results of this study confirm that the determination of the distribution of inheritance for men and women with the provisions of 2: 1 is a form of appointment of the dignity of women who before Islam came to be marginalized. Besides that, this provision is a form of universal Islamic justice for both men and women who have a burden of responsibilities that is both theologically, socially, and economically.
\end{abstract}

Keywords: Formulation, Inheritance, and commentator 


\section{A. PENDAHULUAN}

Allah, Swt., menciptakan alam semesta raya dan segenap isinya dengan segala aturan-aturan yang telah Ia tetapkan (sunnatullāh) sejak zaman azali, tidak terkecuali dengan penciptaan manusia, Allah, Swt., telah menetapkan seperangkat peraturan yang terkait dengan segi kehidupannya di dunia. Dalam hal ini terbagi menjadi dua kelompok. Pertama, berkaitan dengan hubungannya dengan Sang Pencipta (hablun mina Allāh), yang termanifestasikan dengan masalah hukum ibadah. Aturan ini ditetapkan sebagai bentuk penghambaan manusia kepada Tuhannya. Kedua, aturan yang berkaitan dengan hubungannya sesama manusia (hablun mina an-nās), yang termanifestasikan dalam hukum muamalah.

Di antara aturan yang berhubungan antar sesama manusia yang telah diciptakan Allah, Swt., adalah aturan mengenai harta warisan. Hukum waris sangat erat kaitannya dengan ruang lingkup kehidupan manusia, sebab setiap manusia pasti akan mengalami peristiwa hukum yang dinamakan kematian. Akibat hukum yang selanjutnya timbul, dengan terjadinya peristiwa hukum kematian seseorang, di antaranya ialah masalah bagaimana pengurusan dan kelanjutan hakhak dan kewajiban-kewajiban seseorang yang meninggal dunia tersebut. Penyelesaian hak-hak dan kewajibankewajiban sebagai akibat meninggalnya seseorang, diatur oleh hukum waris ${ }^{1}$.

Begitu urgentnya permasalahan waris sampai al-Qur'an sendiri mensyariatkannya secara mendetail/ terperinci. Ketentuan al-Qur'an dalam masalah waris memunculkan polemik, khususnya terkait formulasi 2:1 antara lakilaki dan perempuan. Disatu sisi berpendapat bahwa formulasi tersebut bersifat final (qath'i) sehingga tidak bisa dan tidak dapat dijadikan objek dari ijtihad. Namun disisi lain terdapat pendapat yang mengatakan bahwa formulasi tersebut tidak lepas dengan

\footnotetext{
${ }^{1}$ Eman Suparman, Hukum Waris Indonesia dalam Perspektif Islam, Adat dan BW, Cet. 5, (Bandung: Refika Aditama, 2018), 1.
}

situasi dan kondisi sosial budaya dimana pada saat tersebut kondisi perempuan begitu termarginalkan, sehingga diperlukan reinterpretasi ulang untuk diterapkan pada masa sekarang, dimana keadaan perempuan jauh berbeda dengan pada saat ayat tersebut turun. Dengan munculnya polemik terkait formulasi warisan laki-laki dan perempuan tersebut, penulis tertarik untuk mengkajinya dari perspektif mufassir.

\section{B. PEMBAHASAN}

\section{Konsepsi Dasar Waris}

Di dalam hukum waris telah ditetapkan hak-hak kepemilikan bagi setiap manusia, baik laki-laki maupun perempuan dengan cara yang dibenarkan hukum. Syariat Islam juga menetapkan hak-hak kepemilikan seseorang sesudah ia meningal dunia yang harus diterima seluruh kerabat dan nasabnya dewasa atau anak kecil, semua mendapat hak secara legal ${ }^{2}$. Ungkapan yang digunakan alQur'an untuk menunjukkan adanya kewarisan dapat dilihat pada tiga jenis, yaitu al-irś, al-farāiḍ, dan al-tirkah ${ }^{3}$.

a) $A l-\operatorname{Ir} \dot{s}$

Al-Irs dalam bahasa Arab adalah bentuk mașdar (bentuk dasar) dari kata warisia, yarisu, irsian. Bentuk mașdarnya bukan hanya kata irsian, melainkan termasuk juga kata wirsian, turāisan, dan wirāsatan. Kata-kata itu berasal dari kata asli warisia, yang berakar kata dari huruf-huruf waw, ra, dan $\dot{s} a$ yang bermakna dasar perpindahan harta milik, atau perpindahan pusaka $^{4}$. Kata al-irś juga

2 Abdul Manan, Aneka Masalah Hukum Perdata Islam di Indonesia, (Jakarta: Kencana, 2006), 204-205.

${ }^{3}$ Ali Parman, Kewarisan Dalam Al-Qur'an: Suatu Kajian Dengan Pendekatan Tafsir Tematik, (Jakarta: PT Raja Grafindo Persada, 1995) h. 23. Lihat juga, Maringo, Pembagian Warisan Antara Laki-Laki Dan Perempuan, Skripis: Universitas Islam Negeri Jakarta, 2017.

Qur'an... 23 
semakna dengan kata mīrās, turāsं, dan tirkah, yang artinya warisan ${ }^{5}$.

\section{b) Al-Farāid}

Farāid (فر ائض) adalah bentuk jama' dari kata farị̣̂h (فريضة) yang menurut tinjauan bahasa memiliki banyak makna, diantaranya sebagai berikut: Ata'/ عَ'semberian) ${ }^{6}, A l$ Qat'ul آلَقَطْعُ (ketetapan pasti) ${ }^{7}$, Taqdīr/ تَفْدِيْر(ketentuan) ${ }^{8}$, At-Tabyin/

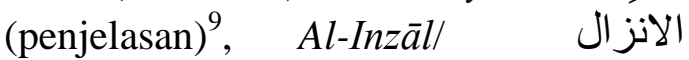
(menurunkan) ${ }^{10}$, dan Al-Iḥlāll الاحلالال, $(\text { menghalalkan })^{11}$. Namun dalam

5 Kamaluddin Nurdin Marjuni, Kamus Syawarifiyyah: Kamus Modern Sinonim ArabIndonesia, (Ciputat: Ciputat Press Group, 2009), 45.

6 Sebagaimana kebiasaan orang Arab bersemboyan dengan mengatakan:

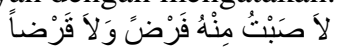

"Sungguh aku telah mendapatkan suatu pemberian artinya bukan hanya janji”.

${ }^{7}$ Sebagaimana firman Allah SWT:

\section{サ}

“...dan bagi perempuan ada bagian dari apa yang ditinggalkan oleh kedua orangtua dan kerabatkerabat, baik sedikit atau banyak, sebagai suatu bagian yang telah ditetapkan..." (QS. An-Nisā' /4: 7). ${ }^{7}$

${ }^{8}$ Sebagaimana firman Allah SWT:

جrV جأن

“...padahal kamu telah menentukan bagi mereka suatu ketentuan (mas kawin), maka karena itu bayarlah separuh dari (jumlah) uang yang telah kamu tentukan..." (QS. Al-Baqarah/2: 237).

${ }^{9}$ Sebagaimana firman Allah SWT:

$$
\text { جت }
$$

"Sesungguhnya Allah SWT telah menjelaskan kepada kamu tebusan sumpah-sumpahmu." (QS. AtTahrīm/66: 2).

$$
\begin{aligned}
& { }^{10} \text { Sebagaimana firman Allah SWT: } \\
& \text { جا }
\end{aligned}
$$

"Sesungguhnya Dzat yang menurunkan Al-Quran kepadamu benar-benar akan mengembalikan kamu ke tempat pengembalian...." (QS. Al-Qașaș/28: 85). ${ }^{10}$

\footnotetext{
${ }^{11}$ Sebagaimana firman Allah SWT:
}

konteks ini, makna yang dikehendaki dari kata Farāid adalah Taqdīr / تَقْدِيْر (ketentuan). Dalam buku Ensiklopedi Hukum Islam dikatakan bahwa Istilah faraid dipakai oleh faradiyyūn dimaknai sebagai mafrüdah, yaitu bagian yang ditentukan kadar jumlahnya, hal ini sebagaimana yang tercermin dalam firman Allah, Swt., dalam QS. An-Nisā 14: 11, yang artinya: "...ini adalah ketetapan dari Allah...".

Kata farīẹh (فريضة) dan yang seasal dengannya terulang 18 (delapan belas) kali dalam al-Qur'an. 8 (delapan) kali dalam bentuk kata kerja masa lalu, di antaranya pada QS. Al-Baqarah/2: 197, QS. AlQașaș/28: 85, serta QS. Al-Aḥzāb/33: 38 dan 50. Satu kali disebut dalam bentuk kata kerja masa sekarang dan masa yang akan datang, seperti dalam QS. Al- Baqarah/2: 236. Di dalam bentuk mașdar (kata yang menunjuk kepada nama benda dan perbuatan) terulang sembilan kali, di antaranya di dalam QS. Al-Baqarah/2: 237, QS. An-Nisā' /4: 11 dan 24, serta ada juga yang disebut dalam bentuk-bentuk lainnya ${ }^{12}$.

c) Al-Tirkah

Kata Al-Tirkah berasal dari bahasa Arab, yaitu bentuk mașdar dari kata taraka, artinya yang ditinggalkan. ${ }^{13}$ Keseluruhan kata taraka yang terdapat dalam surat An-Nisā' /4: 7, 11, 12, 33, dan 176 adalah berbentuk tunggal $m \bar{a} \underline{d i}$, rahasia terbentuknya kata-kata taraka dalam bentuk mạḍi untuk kelima ayat dalam surat An-Nisā' itu karena yang meninggal dunia adalah seorang pewaris. Tirkah yang akan dijadikan pusaka oleh pewaris dapat berupa benda dan sifat-sifat yang memiliki

"Tidak ada suatu dosa pun atas Nabi Muhammad SAW tentang apa yang telah dihalalkan Allah SWT padanya..." (QS. Al-Aḥ̄āb/33: 38).

12 Sahabuddin, Ensiklopedi Al-Quran: Kajian Kosakata, (Jakarta: Lentera hati, 2007), 216217. 
nilai kebendaan. Seperti benda bergerak, benda tidak dapat bergerak, kredit, dan lain-lain.

Dengan uraian di atas, dapat dikemukakan bahwa konsep kewarisan yang terdiri dari al-irs, al-faräid, dan tirkah, ketiganya memiliki unsur-unsur yang berbeda. Istilah yang pertama mengacu kepada sebab terjadinya kewarisan dengan unsur utamanya adalah perkawinan hubungan nasab, dan hubungan wala'. Istilah yang kedua mengacu kepada format saham yang akan diterima ahli waris. Dan istilah ketiga mengacu kepada kewajiban pewaris yang harus dipenuhi ahli warisnya sebelum harta pusakanya dibagi habis oleh ahli warisnya $^{13}$.

Secara terminologi, hukum kewarisan Islam adalah hukum yang mengatur tentang pemindahan hak pemilikan harta peninggalan (tirkah) pewaris 14, menentukan siapa yang berhak menjadi ahli waris dan berapa bagian masing-masing. Hukum waris bisa dikatakan sebagai himpunan peraturan hukum yang mengatur tentang hak dan kewajiban seseorang yang meninggal dunia oleh ahli waris atau badan hukum lainnya.

Dalam Kompilasi Hukum Islam, pengertian hukum kewarisan yaitu hukum yang mengatur tentang pemindahan hak pemilikan harta peninggalan (tirkah) pewaris, menentukan siapa-siapa yang berhak menjadi ahli waris15 dan berapa bagiannya16.

${ }^{13}$ Ali Parman, Kewarisan Dalam Al-
Qur'an... 30-32.

14 Pewaris adalah orang yang pada saat meninggalnya atau dinyatakan meninggal berdasarkan putusan Pengadilan Agama, meninggalkan ahli waris dan harta peninggalan. Lihat Pasal 171 huruf b Kompilasi Hukum Islam.

15 Ahli waris adalah orang yang pada saat meninggal dunia mempunyai hubungan darah atau hubungan perkawinan dengan pewaris, beragama Islam dan tidak terhalang karena hukum untuk menjadi ahli waris. Lihat Pasal 171 huruf c Kompilasi Hukum Islam.

16 Muhammad Amin Suma, Hukum Keluarga Islam di Dunia Islam, (Jakarta: Raja Grafindo Persada, 2004), 1.
Dari definisi di atas, dapat dikatakan bahwa hukum waris ketentuan-ketentuan yang mengatur terkait perpindahan atau peralihan harta orang yang meninggal kepada orang yang berhak menerimanya dengan bagian-bagian sebagaimana yang telah ditetapkan oleh syariat.

\section{Pembagian Waris Dalam Al-Quran}

Dasar hukum waris dalam al-Quran tertuang dalam QS. al-Nisā/4: 7, 11, 12, 33, dan 176 sebagai berikut:

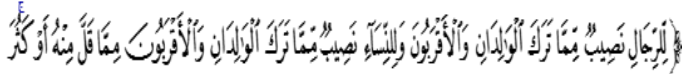

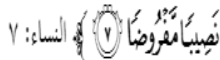

"Bagi orang laki-laki ada hak bagian dari harta peninggalan ibu-bapa dan kerabatnya, dan bagi orang wanita ada hak bagian (pula) dari harta peninggalan ibu-bapak dan kera-batnya, baik sedikit atau banyak menurut bahagian yang telah ditetapkan". (QS. AnNisā/4: 7)

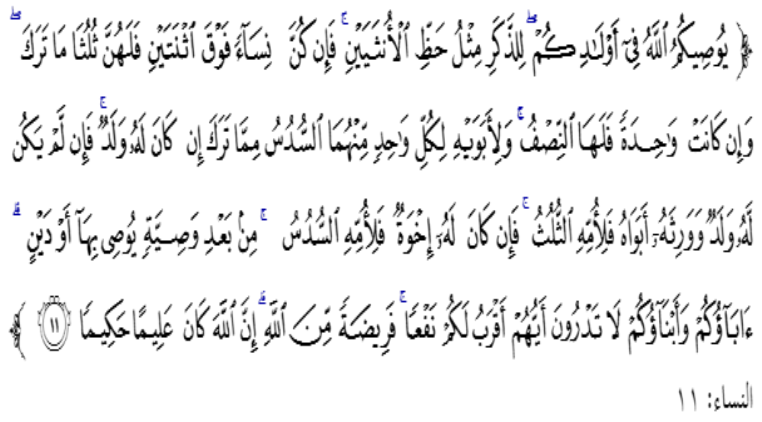

"Allah mensyari'atkan bagimu tentang (pembagian pusaka untuk) anak-anakmu. Yaitu : bahagian seorang anak lelaki sama dengan bagian dua orang anak perempuan; dan jika anak itu semuanya erempuan lebih dari dua, maka bagi mereka dua pertiga dari har-ta yang ditinggalkan; jika anak perempuan itu seorang saja, Maka ia memperoleh sepa-ro harta. dan untuk dua orang ibubapak, bagi masing-masingnya 
seperenam dari har-ta yang ditinggalkan, jika yang meninggal itu mempunyai anak; jika orang yang meninggal tidak mempunyai anak dan ia diwarisi oleh ibu bapaknya (saja), Maka ibunya mendapat sepertiga; jika yang meninggal itu mempu-nyai beberapa saudara, Maka ibunya men-dapat seperenam. (Pembagian-pembagian tersebut di atas) sesudah dipenuhi wasiat yang ia buat atau (dan) sesudah dibayar hu-tangnya. (Tentang) orang tuamu dan anak-anakmu, kamu tidak mengetahui siapa di antara mereka yang lebih dekat (banyak) manfaatnya bagimu. ini adalah ketetapan dari Allah. Sesungguhnya Allah Maha menge-tahui lagi Maha Bijaksana”. (QS. An-Nisā/4 : 11)

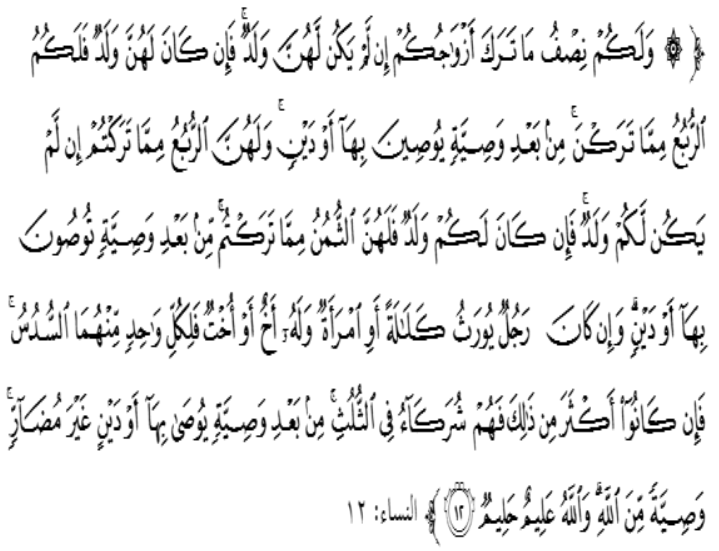

"Dan bagimu (suami-suami) seperdua dari harta yang ditinggalkan oleh isteri-isterimu, jika mereka tidak mempunyai anak. jika isteri-isterimu itu mempunyai anak, Maka kamu mendapat seperempat dari harta yang diti-nggalkannya sesudah dipenuhi wasiat yang mereka buat atau (dan) seduah dibayar hu-tangnya. Para isteri memperoleh seperem-pat harta yang kamu tinggalkan jika kamu tidak mempunyai anak. jika kamu mempu nyai anak, Maka Para isteri memperoleh seperdelapan dari harta yang kamu tinggal-kan sesudah dipenuhi wasiat yang kamu buat atau (dan) sesudah dibayar hutang-hutangmu. jika seseorang mati, baik laki-laki maupun perempuan yang tidak mening-galkan ayah dan tidak meninggalkan anak, tetapi mempunyai seorang saudara laki-laki (seibu saja) atau seorang saudara perem-puan (seibu saja), Maka bagi masingmasing dari kedua jenis saudara itu seperenam har-ta. tetapi jika saudara-saudara seibu itu lebih dari seorang, maka mereka bersekutu dalam yang sepertiga itu, sesudah dipenuhi wasiat yang dibuat olehnya atau sesudah dibayar hutangnya dengan tidak memberi mudharat (kepada ahli waris). (Allah menetapkan yang demikian itu sebagai) syarî'at yang benarbenar dari Allah, dan Allah Maha mengetahui lagi Maha Penyantun". (QS. An-Nisā/4: 12)

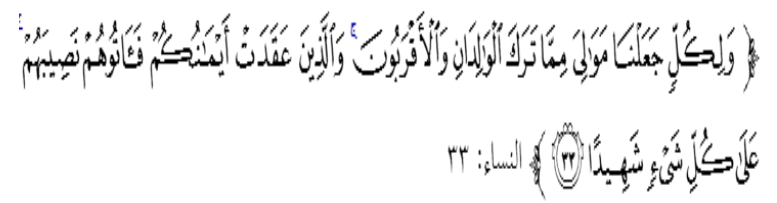

"Dan bagi tiap-tiap harta peninggalan dari har-ta yang ditinggalkan ibu bapak dan karib ke-rabat, Kami jadikan pewaris-pewarisnya dan (jika ada) orang-orang yang kamu telah ber-sumpah setia dengan mereka, Maka berilah kepada mereka bahagiannya. Sesungguhnya Allah menyaksikan segala sesuatu." (QS. An-Nisā/4: 33) 


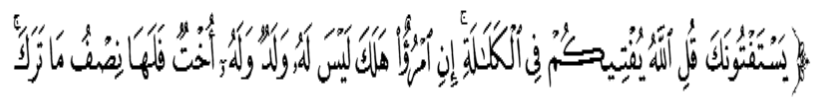

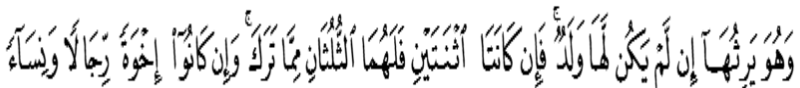

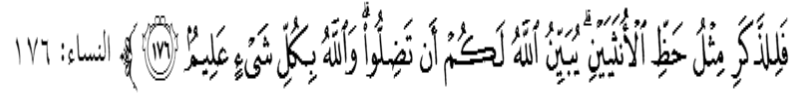

"Mereka meminta fatwa

kepadamu (tentang kalalah).

Katakanlah: "Allah memberi

fatwa kepadamu tentang

kalalah (yaitu): jika se-orang

meninggal dunia, dan ia tidak

mempu-nyai anak dan

mempunyai saudara perem-

puan, Maka bagi saudaranya

yang perem-puan itu seperdua

dari harta yang ditinggal-

kannya, dan saudaranya yang

laki-laki mem-pusakai (seluruh

harta saudara perempuan),

jika ia tidak mempunyai anak;

tetapi jika sau-dara perempuan

itu dua orang, Maka bagi

keduanya dua pertiga dari

harta yang ditinggalkan oleh

yang meninggal. dan jika

mereka (ahli waris itu terdiri

dari) saudara-saudara laki dan

perempuan, Maka bahagian

seorang saudara laki-laki

sebanyak bahagian dua orang

saudara perempuan. Allah

menerang-kan (hukum ini)

kepadamu, supaya kamu tidak

sesat. dan Allah Maha

mengetahui se-gala sesuatu”.

(QS. An-Nisā/4: 176)

Ayat-ayat di atas turun untuk merekonstruksi sistem pewarisan yang selama ini berlaku pada masyarakat Arab jahiliyyah. Sebab jauh sebelum Islam datang, masyarakat Arab Jahiliyah sudah mengenal dan menetapkan sistem kewarisan yang mereka gunakan. Sistem kewarisan yang berlaku saat itu dipengaruhi oleh sistem sosial masyarakat yang sudah turun temurun. Masyarakat Arab jahiliyah cenderung dikenal sebagai masyarakat kesukuan, nomaden, suka berperang, dan bermata pencaharian sebagai peternak walaupun ada sebagian dari mereka yang bermata pencaharian sebagai pedagang-turut membentuk norma-norma, sistem hukum dan sosial yang berlaku. Kondisi itu pula yang mempengaruhi dan menjadikan kekuatan fisik sebagai ukuran baku dalam membentuk sistem kewarisan yang berlaku.

Bagi mereka, ahli waris yang berhak mendapatkan harta peninggalan dari keluarganya yang meninggal, adalah hanya laki-laki, yang berfisik kuat dan mengalahkan musuh dalam setiap peperangan. Karena dari prestasi dan eksistensi suku itulah, martabat seseorang sebagai anggota suku dipertaruhkan. Konsekuensinya adalah anak- anak baik laki-laki maupun perempuan tidak diberi hak mewarisi harta peninggalan keluarganya. Ketentuan semacam ini telah menjadi tradisi dan mengakar kuat di dalam masyarakat. Bahkan seperti diketahui, fenomena penguburan hidup-hidup terhadap anak perempuan, merupakan suatu fakta sejarah yang tidak bisa ditutup-tutupi. Praktis perempuan mendapat perlakuan yang sangat deskriminatif. Mereka tidak bisa menghargai kaum perempuan, yang nantinya dalam perspektif al-Qur'an mempunyai kedudukan yang sederajat dengan laki-laki. Bagi mereka, kaum perempuan tidak ubahnya bagaikan barang, bisa diwariskan dan diperjual belikan, bisa dimiliki dan dipindah-pindahkan ${ }^{17}$. Alasan mereka kenapa wanita cenderung dimarginalkan sehingga tidak memperoleh

17 Ahmad Rafiq, Fiqh Mawaris, Cet. 4, (Jakarta: PT. Raja Grafindo Persada, 2002), 8. Penggambaran kedudukan perempuan pada masa Arab jahiliyyah sebagaimana yang katakan oleh Ibn Abbas ketika beliau mengomentari terkait turunnya QS. An-Nisā/4: 19. Dimana beliau mengatakan: "Dahulu, apabila seorang laki-laki ada yang meninggal, walinya berhak (mendapatkan) isterinya. Jika sebagian mereka menginginkan, mereka menikahinya, dan juga bisa menikahkannya (dengan orang lain) atau tidak menikahkannya, yang pasti mereka berhak (memperlakukan apa saja) terhadapnya daripada keluarganya sendiri”. Lihat, Abu Nizhan, Mutiara Shahih Asbabun Nuzul, (Bandung: Salamadani, 2011), 61. 
hak-haknya sebagai manusia, sebagaimana laki-laki adalah:

"Bagaimana mungkin kami akan memberikan warisan kepada orang yang tidak pernah menunggang kuda, tidak pernah memanggul senjata, dan tidak pernah berperang melawan musuh." 18

Dengan realitas tersebut, maka alQur'an turun untuk mengoreksi adat istiadat yang mengakar pada masyarakat Arab Jahiliyyah yang cenderung merugikan kaum perempuan, khususnya dalam masalah kewarisan, dimana mereka tidak memiliki hak untuk mendapatkannya bahkan dijadikan objek dari warisan itu sendiri. Sehingga dengan koreksi tersebut perempuan mendapatkan hak mereka dalam masalah kewarisan.

Hal ini sebagaimana yang dikatakan Nasr Hāmid Abū Zayd berpendapat bahwa sebelum Islam datang, masyarakat Arab ketika itu menganut sistem kewarisan patriarkat dan menganggap perempuan tidak berhak memperoleh harta waris sedikit pun. Kemudian Islam mengubah aturan ini, seperti yang termaktub dalam QS. AnNisā/4: 11). Menurut dia, ayat ini menekankan adanya perubahan hukum kewarisan di tengah masyarakat, yaitu perempuan diberikan hak waris ${ }^{19}$.

Sistem kewarisan yang berlaku tersebut telah mendarah daging pada masyarakat Arab pra Islam dikala itu, walaupun mereka sendiri telah menjadi seorang muslim. Bahkan dikalangan mereka berharap pemberian kewarisan kepada perempuan dan anak-anak diganti karena bertolak belakang dengan tradisi dan kebiasaan yang mereka lakukan.

Menurut Fakhruddin ar-Razi sebagaimana yang diungkap oleh Neni

18 Ali Ash-Shabuni, Kitab Ilmu Waris: Mengupas Persoalan Waris Sesuai al-Qur'an dan Sunnah, Penerjemah: M. Syauqi Mubarak, (Jakarta: Turos Pustaka, 2019), 19.

${ }^{19}$ Khaeron Sirin, “Analisis Pendekatan Teks dan Konteks dalam Penentuan Pembagian Waris Islam”. (AHKAM: Jurnal Ilmu Syariah, 2013), 13.
Nuraeni dalam tulisannya "Tafsir Ayat Ahkām Gender (Kajian tentang Bagian Hak Waris dan Kepemimpinan Perempuan)" mengatakan bahwa pandangan ini bahkan masih diikuti oleh orang-orang yang telah masuk Islam sekali pun, sampai suatu saat ada yang mengadukan persoalan mereka kepada Rasulullah Saw., seperti yang dilakukan oleh janda Sa'ad ibnu al-Rabbi'. Dia mengeluhkan kepada Rasulullah Saw., bahwa dua anak perempuan Sa'ad sama sekali tidak mendapatkan warisan dari harta peninggalan bapak mereka. Saudara lakilaki Sa'ad mengambil harta peninggalan Sa'ad tanpa tersisa sedikit pun untuk kedua anak perempuannya. Menanggapi keluhan janda Sa'ad ibnu al-Rabbi' tersebut, tidak lama kemudian turunlah QS. An-Nisā/4: 11$12^{20}$.

Selain kasus janda dan kedua anak perempuan Sa'ad di atas, diriwayatkan juga kasus lain yang melatarbelakangi turunnya dua ayat tentang warisan tersebut. Diriwayatkan oleh Ibn Jarir bahwa setelah Hasan bin Tsabit meninggal dunia, beberapa ahli waris laki-laki dari keluarga Hasan datang mau mengambil semua peninggalan harta almarhum. Padahal Hasan meninggalkan seorang Istri bernama Hakkah dan lima orang anak perempuan. Melihat kejadian itu, Hakkah pergi melaporkan nasibnya dan kelima anak perempuannya kepada Rasulullah, Saw., dan turunlah ayat yang menjelaskan tentang pembagian warisan.

"Allah mensyari'atkan bagimu
tentang (pembagian pusaka untuk)
anak-anakmu. Yaitu : bahagian
seorang anak lelaki sama dengan
bagahian dua orang anak
perempuan; dan jika anak itu
semuanya perempuan lebih dari dua,
maka bagi mereka dua pertiga dari
harta yang ditinggalkan; jika anak
perempuan itu seorang saja, maka ia
memperoleh separo harta. Dan untuk

20 Neni Nuraeni, "Tafsir Ayat Ahkâm Gender (Kajian Tentang Bagian Hak Waris Dan Kepemimpinan Perempuan)", Asy-Syari'ah, 16(1), 2014, 25-34. 
dua orang ibu-bapak, bagi masingmasingnya seperenam dari harta yang ditinggalkan, jika yang meninggal itu mempunyai anak; jika orang yang meninggal tidak mempunyai anak dan ia diwarisi oleh ibu bapaknya (saja), Maka ibunya mendapat sepertiga; jika yang meninggal itu mempu-nyai beberapa saudara, Maka ibunya men-dapat seperenam. (Pembagianpembagian tersebut di atas) sesudah dipenuhi wasiat yang ia buat atau (dan) sesudah dibayar hu-tangnya. (Tentang) orang tuamu dan anakanakmu, kamu tidak mengetahui siapa di antara mereka yang lebih dekat (banyak) manfaatnya bagimu. ini adalah ketetapan dari Allah. Sesungguhnya Allah Maha mengetahui lagi Maha Bijaksana." (QS. An-Nisā/4 : 11)

"Dan bagimu (suami-suami)
seperdua dari harta yang ditinggalkan oleh isteri-isterimu, jika mereka tidak mempunyai anak. jika isteri-isterimu itu mempunyai anak, Maka kamu mendapat seperempat dari harta yang diti-nggalkannya sesudah dipenuhi wasiat yang mereka buat atau (dan) seduah dibayar hutangnya. Para isteri memperoleh seperem-pat harta yang kamu tinggalkan jika kamu tidak mempunyai anak. jika kamu mempu nyai anak, Maka Para isteri memperoleh seperdelapan dari harta yang kamu tinggal-kan sesudah dipenuhi wasiat yang kamu buat atau (dan) sesudah dibayar hutanghutangmu. jika seseorang mati, baik laki-laki maupun perempuan yang tidak mening-galkan ayah dan tidak meninggalkan anak, tetapi mempunyai seorang saudara lakilaki (seibu saja) atau seorang saudara perem-puan (seibu saja), Maka bagi masing-masing dari kedua jenis saudara itu seperenam har-ta. tetapi jika saudara-saudara seibu itu lebih dari seorang, maka mereka bersekutu dalam yang sepertiga itu, sesudah dipenuhi wasiat yang dibuat olehnya atau sesudah dibayar hutangnya dengan tidak memberi mudharat (kepada ahli waris). (Allah menetapkan yang demikian itu sebagai) syarî'at yang benar-benar dari Allah, dan Allah Maha mengetahui lagi Maha Penyantun”. (QS. An-Nisā/4: 12)

Dalam dua ayat di atas diuraikan secara terperinci ketentuan pembagian harta warisan. Siapa-siapa yang berhak mendapatkan warisan, berapa bagian masing-masing, kapan seseorang mendapat bagian warisan yang tetap (bi al-fard), kapan pula ia mendapat bagian warisan berdasarkan kelebihan harta ('așabah), kapan seseorang memperoleh hak warisan berdasarkan dua sistem tersebut (tetap dan kelebihan), dan siapa-siapa ahli waris yang terhalang haknya oleh ahli waris yang lain berdasarkan kedekatan hubungan darah atau kerabat, baik secara keseluruhan maupun sebagian, dan ketentuan-ketentuang lain tentang warisan ${ }^{21}$.

Apabila kita pahami secara tekstual terkait kedua ayat di atas dapat ditarik suatu kesimpulan bahwa penyebab timbulnya saling mewarisi dalam Islam adalah karena sebab hubungan nasab (darah) dan perkawinan. Dari jalur nasab atau hubungan darah yang masuk dalam kategori ahli waris adalah keluarga terdekat baik anak laki-laki, anak perempuan, ayah, ibu dan para saudara baik laki-laki maupun perempuan. Sementara dari jalur perkawinan adalah suami dan istri. Dengan demikian ahli waris inti adalah anak laki-laki, anak perempuan, ayah, ibu, dan suami/ isteri. Keenam orang tersebut masuk dalam kategori ahli waris inti karena merupakan ahli waris terpenting yang menjadi prioritas pembagian harta warisan. Oleh sebab itu, mereka tidak dapat

21 Nurjannah Ismail, Perempuan Dalam Pasungan, (Yogyakarta: LkiS, 2003), 199. 
digugurkan haknya sebagai pewaris karena sebab ada pewaris lain (Hajb hirman ${ }^{22}$ ), dan sepanjang mereka masih hidup pada saat pewaris meninggal dunia maka para ahli waris inti tersebut pasti memperoleh bagian sesuai dengan kadar bagian masing-masing.

Hal ini berbeda dengan sistem kewarisan pra Islam, dalam hal ini menurut Rasyid Ridla menjelaskan bahwa pada zaman pra-Islam, sebab-sebab terjadinya pewarisan itu ada tiga. Pertama, karena ada hubungan nasab (al-nasab). Namun, hubungan nasab ini hanya dikhususkan buat laki-laki dewasa yang bisa menunggang kuda, memerangi musuh, memperoleh harta rampasan perang. Dengan demikian, anak laki-laki yang masih kecil dan kaum perempuan tak mendapatkan bagian waris. Kedua, karena ada hubungan anak angkat (al-tabanni). Anak angkat mendapatkan bagian waris pada zaman pra-Islam sekalipun yang bersangkutan tak punya hubungan darah dengan ayah atau ibu angkatnya. Ketiga, karena ada sumpah dan kesepakatan. Sekiranya seseorang berkata kepada salah seorang temannya, "darahku, darahmu juga, hartaku adalah hartamu juga, antara engkau dan aku saling mewarisi, kau bisa meminta kepadaku dan aku pun bisa meminta kepadamu". Jika mereka bersepakat, sekiranya salah satu dari keduanya meninggal dunia, maka terjadi hubungan kewarisan di antara mereka ${ }^{23}$.

Dari perbedaan penyebab saling mewarisi dalam Islam dengan sistem yang berlaku pada masa pra Islam kita dapat menarik perbedaan yang ada dalam kedua

${ }^{22}$ Hajb hirman yaitu penghalang yang menggugurkan seluruh hak waris seseorang. Misalnya, terhalangnya hak waris seorang kakek karena adanya ayah, terhalangnya hak waris cucu karena adanya anak, terhalangnya hak waris saudara seayah karena adanya saudara kandung, terhalangnya hak waris seorang nenek karena adanya ibu, dan seterusnya. Lihat, Muhammad Ikbal, "Hijab Dalam Kewarisan". At-Tafkir, 11(1), (2018), 132-153.

23 Lihat, Abdul Moqsith Ghazali dalam tulisannya yang berjudul "Hukum Waris dalam Suatu Konteks".http://wahidinstitute.org/v1/Opini/Detail/?i d=291/hl=id/Hukum_Waris_Dalam_Suatu_Konteks. Diakses pada tanggal 10 Januari 2019. sistem waris tersebut. Di dalam Islam, penyebab saling mewarisi adalah karena sebab nasab dan kewarisan. Hal ini menunjukkan bahwa perhatian Islam terhadap nasib kesejahteraan orang-orang terdekat pewaris -baca: ahli waris utama-menjadi fokus utama, sehingga mereka tidak menjadi terpuruk dan lemah secara ekonomi sepeninggal pewaris. Berbeda halnya dengan sistem kewarisan pra Islam, dimana sistem kewarisan yang berlaku tersebut tidak mengakomodir dan tidak memperhatikan nasib orang-orang terdekat pewaris, khususnya perempuan (istri) dan anak-anak, sehingga nasib mereka secara ekonomi menjadi lemah dan terpuruk pasca meninggalnya pewaris. Hal inilah yang menjadi kritik dari syariat Islam itu sendiri, yang kemudian merekonstruksi sistem yang berlaku pada saat itu.

Al-Qur'an tidak hanya sekedar merinci siapa saja yang berhak menjadi ahli waris, namun juga ditetapkan porsi jumlah bagian yang diperoleh baik bagi laki-laki maupun perempuan. Terkait penjelasan ayat waris yang berkenaan dengan porsi yang diterima ahli waris laki-laki maupun perempuan di atas, Fadlih Rifenta dalam tulisannya yang Konsep Adil Dalam Hukum Waris Islam dijelaskan sbagai berikut: ${ }^{24}$

Pertama, Laki-laki mendapat jumlah yang sama banyak dengan perempuan: seperti ibu dan ayah (sama-sama mendapatkan $1 / 6$ [satu per enam]) dalam keadaan pewaris meninggalkan anak kandung. Begitu pula saudara lakilaki dan saudara perempuan sama-sama mendapatkan 1/6 (satu per enam) (dalam kasus pewaris adalah seorang yang tidak memiliki ahli waris langsung).

Kedua, Laki-laki memperoleh bagian lebih banyak atau dua kali lipat dari yang didapat oleh perempuan dalam kasus yang sama yaitu anak laki-laki dengan anak perempuan. Dalam kasus yang terpisah duda mendapat dua kali bagian yang diperoleh oleh janda yaitu $1 / 2$ (satu per dua) berbanding

24 Fadlih Rifenta, "Konsep Adil Dalam Hukum Waris Islam", Ijtihad: Jurnal Hukum dan Ekonomi Islam, (2019), 13(1), 55-71. 
$1 / 4$ (satu per empat) bila pewaris tidak ada meninggalkan anak; dan $1 / 4$ (satu per empat) banding $1 / 8$ (satu per delapan) bila pewaris meninggalkan anak.

Ketiga bagian perempuan lebih banyak dari laki-laki, Hal ini setidaknya bisa dilihat dari dua sisi : Sisi pertama, lebih banyaknya kaum perempuan dari pada lakilaki dalam posisi aṣhābul furūd. Dalam Islam ahli waris dikelompokkan menjadi dua așhābul furūd dan aṣabah. Dalam AlQura'n disebutkan bahwa așhābul furūd berjumlah 12 (dua belas) orang. 8 (delapan) orang dari perempuan yaitu: ibu, nenek, istri, anak perempuan, cucu perempuan, saudari kandung, saudari sebapak, dan saudari seibu. 4 (empat) dari laki-laki yaitu, ayah, kakek, suami, dan saudara laki-laki seibu. Bagian terbesar dalam warisan adalah $2 / 3$ (dua pertiga), dan ahli waris yang mendapatkan jatah $2 / 3$ (dua pertiga) itu semuanya perempuan, yaitu 2 (dua) anak perempuan atau lebih, 2 (dua) saudari kandung atau lebih, 2 (dua) saudari sebapak atau lebih, 2 (dua) saudari seibu.

Keempat, bagian perempuan lebih sedikit dibandingkan pihak laki-laki, yang dalam hal ini terdapat dalam 4 (empat) kasus: 1), apabila anak perempuan dan lakilaki, maka anak perempuan mendapatkan setengah dari bagian laki-laki. 2) apabila terdapat ayah dan ibu pewaris, sedangkan dia tidak mempunyai keturunan, dan juga tidak mempunyai istri atau suami maka ibu mendapatkan $1 / 3$ (satu pertiga), dan sisanya adalah bagian ayah. 3) apabila terdapat saudara dan saudari kandung dari pewaris, dan dia tidak memiliki anak dan orang tua. Maka saudari kandung mendapatkan $1 / 3$ (satu pertiga) dan sisanya $2 / 3$ (dua pertiga) untuk saudara laki-laki kandung. Sebagaimana firman Allah, Swt., dalam surat An-Nisā/4: 176. 4), apabila terdapat saudara laki-laki sebapak, dan saudari perempuan sebapak, dan jika pewaris tidak memiliki saudara kandung, anak, dan orang tuan, maka saudara perempuan $1 / 3$ (satu pertiga) dan sisanya $2 / 3$ (dua pertiga) untuk saudara lakilaki sebapaknya.

\section{Formulasi Waris Laki-Laki Dan Perempuan Perspektif Mufassir}

Sebagaimana telah dibahas dalam sub bab sebelumnya bahwa sistem kewarisan yang berlaku pada era pra Islam cenderung bersikap diskriminatif kepada perempuan, sehingga hak-hak perempuan khususnya dalam masalah waris diabaikan, bahkan lebih dari itu, dianggap sebagai objek waris itu sendiri. Kehadiran Islam dengan ajarannya yang memanusiakan manusia khususnya berkaitan dengan derajat perempuan membawa angin segar bagi mereka. Hak-hak yang selama ini tidak mereka dapatkan, karena dianggap tidak memiliki peran apapun baik dalam hal power maupun materi, akhirnya terangkat dengan sebab dakwah Islam yang dibawa oleh Rasulullah Muhammad, Saw., khususnya dalam masalah kewarisan.

Al-Quran dan sunnah sebagai sumber dari ajaran Islam telah membuat formulasi baru terkait dengan regulasi hukum kewarisan yang tentu saja menampakkan sisi keadilan dan persamaan hak. Formulasi yang telah ditetapkan al-Qur'an tersebut memunculkan beragam pemahaman dikalangan umat Islam sendiri, khususnya para mufassir.

Sebagaimana yang dikatakan oleh Abdullah Saeed, bahwa al-Qur'an sebagai sebuah teks, membutuhkan penafsiran sebagaimana teks-teks yang lain. Para pengkaji al-Qur'an sejatinya bukanlah para pengkaji yang netral dan objektif, namun dengan membawa bias dan cakrawalanya sendiri. Oleh sebab itu, perbedaan pengalaman hidup, kesan, nilai, dan lingkungan kultural tiap-tiap individu akan membentuk makna dengan cara yang berbeda untuk mencapai pemahaman mereka terhadap teks itu sendiri ${ }^{25}$.

Dengan demikian dari apa yang diungkapkan oleh Abdullah Saeed di atas dapat dikatakan bahwa penafsiran para mufassir terhadap al-Qur'an secara tidak

25 Abdullah Saeed, Al-Qur'an Abad 21, penerjemah: Ervan Nurtawab, (Bandung: Mizan, 2016), 27. 
langsung dan tanpa disadari oleh mufassir itu sendiri bahwa penafsiran mereka tidak bebas nilai, dalam arti terpengaruh dengan konteks yang berada disekililingnya, baik kondisi budaya, politik, ekonomi, dan pengalaman hidupnya dalam corak penafsiran yang diberikan. Oleh sebab itu, setiap bentuk tafsir yang muncul dalam khazanah tafsir al-Qur'an tidak bersifat netral dan objektif. Begitupun penafsiran mereka terhadap ayat-ayat waris, khususnya terkait formulasi bagian waris laki-laki dan perempuan yaitu 2:1 (baca: dua berbanding satu) yang sampai saat ini masih menimbulkan polemik dikalangan umat Islam sendiri, khususnya dikalangan mufassir. Adapun makna dari ayat yang memunculkan polemik tersebut adalah: "Allah mensyari'atkan bagimu tentang (pembagian pusaka untuk) anak-anakmu. Yaitu : bagian seorang anak lelaki sama dengan bagian dua orang anak perempuan..." (QS. An-Nisā/4: 11).

Mengomentari makna QS. Al-Nisā/4: 11 di atas, Imam Ath-Thabari mengatakan bahwa ayat tersebut tidak bermaksud mengungkapkan kekurangan perempuan. Namun menunjukkan persamaan laki-laki dan perempuan yaitu sebagai pihak yang menerima warisan. Sebab, menurut beliau, karena pada masa pra Islam (masa jahiliyyah) perempuan dan anak-anak tidak menerima warisan. Alasan yang mereka berikan adalah karena perempuan dan anakanak tidak pernah memegang senjata, dan tidak pernah berperang melawan musuh, sebagaimana yang diungkapkan dalam latar belakang turunnya ayat tersebut. Oleh sebab itu, sudah cukup bagian laki-laki dua kali lebih banyak dibandingkan perempuan, tanpa harus mengharamkan sama sekali bagi perempuan untuk mendapatkan kewarisan ${ }^{26}$.

Dari penafsiran Imam Aț- Tabari di atas, beliau hanya mengungkapkan tujuan dan setting social pada saat ayat tersebut turun, namun beliau tidak mempertanyakan ataupun menjelaskan kenapa bagian

${ }^{26}$ Ibn Jarir Aț-Ṭabari, Jāmi' al-Bayān fì Tafsìr al-Qur'ān, jilid III, (Beirut: Dār al-Fikr, Tt), 216-217. perempuan lebih sedikit dibandingkan bagian laki-laki dalam hal waris. Menurut Nurjannah Ismail, bahwa persoalan tersebut tidak diangkat oleh Imam At-Ṭabari karena pada saat itu belum munculnya pertanyaan terkait perbedaan jumlah bagian yang diterima perempuan dibandingkan lakilaki ${ }^{27}$. Menurut penulis hal ini dapat dimaklumi, karena peran perempuan dalam lingkungan masyarakat pada saat itu belum memiliki ruang, terlebih lagi warisan budaya secara turun temurun bersifat patrialisme. Sehingga ruang perempuan pada saat itu terbatas hanya pada sumur, dapur, dan kasur. Terlebih lagi isu-isu kesetaraan gender mulai dibicarakan dikalangan intelektual muslim pada abad XX (dua puluh). Baik dalam tinjauan yang bersifat umum, khususnya menyangkut hak-hak dan pemberdayaan perempuan maupun yang dikaitkan dengan pemikiran Islam khususnya tentang penafsiran ayat-ayat yang berhubungan dengan masalah perempuan.

Imam Fakhruddi ar-Razi dalam Tafsìr al-Kabir mengungkapkan alasan kenapa bagian perempuan lebih sedikit dibandingkan laki-laki dalam masalah kewarisan, menurutnya karena laki-laki lebih utama dibandingkan perempuan, sehingga laki-laki disebut lebih awal; karena keutamaan laki-laki seimbang (muțābawah) dengan perempuan secara pasti; dan karena penyebab turunnya ayat tersebut di atas disebabkan mereka -masyarakat Arab pra Islam-hanya memberikan warisan kepada laki-laki, tidak sama sekali kepada perempuan. Dari sini wajarlah apabila bagian laki-laki dua kali lipat dibandingkan bagian perempuan, dan tidak sepantasnya pihak laki-laki menghalangi perempuan untuk mendapatkan warisan dengan cara menguasai sepenuhnya harta waris tersebut ${ }^{28}$.

Secara sepintas, penjelasan oleh Imam Aț-Ṭabari dan Imam ar-Razi di atas terkait pemahamannya pada QS. Al-Nisā/4:

27 Nurjannah Ismail, Perempuan Dalam Pasungan... 203.

${ }^{28}$ Fakhruddin ar-Razi, Tafsīr al-Kabìr, Jilid IX, (Beirut: Dār al-Fikr, 1995), 207. 
11, keduanya sepakat dan mengamini apa yang telah ditetapkan al-Qur'an. Bagi kedua mufassir di atas, pemberian hak waris kepada perempuan yang dilakukan alQur'an adalah sebagai bentuk pengangkatan martabat perempuan, dimana keduanya mengaitkan pemberian waris kepada perempuan dengan kondisi realitas pada saat itu yang tidak memberikan bagian waris kepada perempuan juga kepada anak-anak.

Begitupun Muhammad Abduh dalam Tafsìr al-Qur'ān pun mengatakan hal yang sama, menurutnya ayat di atas mengisyaratkan penghormatan Islam terhadap martabat perempuan. Pada ayat ini pembagian warisan perempuan dijadikan dasar untuk memberikan bagian warisan bagi laki-laki, padahal sebelum Islam datang perempuan tidak mempunyai hak atas warisan keluarganya ${ }^{29}$.

Realitas mufassir baik Aț-Ṭabari, ArRazi, maupun Muhammad Abduh dalam menjelaskan pemahaman mereka terhadap ayat waris dengan setting social pada saat ayat tersebut turun, sebab Al-Qur'an hadir di tengah masyarakat yang sudah memiliki sistem sosial dan hukum. Proses turunnya Al-Qur'an sebagai sumber hukum, sebagian besar merupakan respon balik terhadap sistem sosial dan hukum yang hidup di tengah masyarakat ketika itu. Respon balik dimaksud di antaranya; Pertama, sistem sosial dan hukum yang ada tetap diberlakukan setelah diperbaiki, baik dengan penambahan maupun pengurangan, misalnya, dalam hukum keluarga dan kewarisan, perempuan dalam keluarga sama sekali berada pada posisi yang sangat lemah dan hak kewarisannya pun tidak ada sama sekali. Terhadap sistem hukum yang seperti, diperbaiki oleh hukum Islam dengan menempatkan perempuan pada porsinya dan mengakui akan hak kewarisannya. Kedua, sistem sosial dan hukum yang berlaku ditolak secara keseluruhan, misalnya, hukum pengangkatan anak angkat. Ketiga, hukum Islam mengenalkan sistem hukum baru,

${ }^{29}$ Muhammad Abduh, Tafsìr al-Qur'ān alHak̄̄m al-Syah̄̄r bi Tafs̄̄r al-Manār, jilid V, (Bairut: Dar al-Fikr, Tt), 171.

misalnya, hukum hutang piutang yang mensyaratkan untuk ditulis dengan menghadirkan para saksi ${ }^{30}$.

Dengan demikian untuk menghindari pemahaman yang diskriminatif, menurut Rașīd Riḍa ayat ini harus dipahami secara komprehensif. Pemberian warisan lebih banyak untuk anak laki-laki dari pada anak perempuan, harus dilihat secara bijak. Dalam Islam laki-laki diwajibkan untuk menafkahi istri dan keluarganya, sedangkan perempuan tidak diwajibkan untuk menafkahi orang lain ${ }^{31}$.

Ali Aș-Șabuni menjelaskan secara rinci hikmah dibalik penetapan jumlah waris laki-laki lebih dibandingkan perempuan, menurutnya hikmah tersebut adalah sebagai berikut: ${ }^{32}$

1. Biaya dan kebutuhan hidup perempuan telah dijamin. Kewajiban menafkahinya dibebankan kepada anak laki-laki, ayah, saudara laki-laki, atau kerabatnya yang lain;

2. Perempuan tidak dibebani menafkahi siapapun, berbeda halnya dengan laki-laki yang dibebani menafkahi anggota keluarga, sanak saudara, dan orang-orang yang diwajibkan untuk dinafkahi olehnya;

3. Jumlah nafkah yang harus dikeluarkan laki-laki lebih gemuk dan kewajiban-kewajiban finansialnya lebih banyak , sehingga kebutuhan akan harta jauh lebih besar dibandingkan perempuan;

4. Laki-laki berkewajiban memberikan mahar kepada istrinya dan bertanggung jawab menyediakan sandang, paangan,

\footnotetext{
${ }^{30}$ Bakhtiar, "Peranan Asbab Al-Nuzul dalam Penemuan Hukum", (Jurnal Imam Bonjol: Kajian Ilmu Informasi dan Perpustakaan, 2018), 54-69.

31 Rasyīd Riḍā, Tafsīr al-Manār, Jilid 4, (Kairo: Dar al-Manār, Tt), 406.

${ }^{32}$ Ali Ash-Shabuni, Kitab Ilmu Waris... 1415
} 
dan papan kepada anak dan istrinya;

5. Biaya pendidikan anak dan pengobatan istri serta anakanaknya ditanggung oleh lakilaki.

Dengan bentuk tanggung jawab besar yang dimiliki laki-laki, maka bagi kalangan mufassir penetapan formulasi yang dilakukan al-Qur'an sudah sesuai, dan hal ini merupakan bentuk keadilan yang ditekankan al-Qur'an. Karena keadilan itu sendiri tidak harus sama rata, namun disesuaikan dengan kodrat, fungsi, dan tugas yang dibebankan kepada laki-laki dan perempuan. Laki-laki memiliki beban untuk membayar mahar, membelanjai istri dan anak-anaknya, sedangkan perempuan tidaklah demikian. Perempuan apabila memiliki harta, maka harta tersebut hanya untuk dirinya sendiri dan tidak diwajibkan untuk membelanjai suaminya ataupun anaknya. Oleh sebab itu, M. Quraish Shihab, hal ini mengandung penekanan pada bagian anak perempuan, karena dengan dijadikannya bagian anak perempuan sebagai ukuran bagi anak laki-laki. Dengan begitu sejak semula sebelum ditetapkannya bagian laki-laki, terlebih dahulu telah ditetapkan bagian bagi perempuan. Seperti halnya ketika ingin mengukur sesuatu tentunya harus memiliki alat ukurnya, barulah dapat mengukur ukuran sesuatu itu. Penggunaan redaksi ini adalah untuk menjelaskan hak perempuan memperoleh warisan, dan tidaklah seperti yang diberlakukan pada masa jahiliyah ${ }^{33}$.

Asy-Sya'rawi sendiri sebagaimana yang dinyatakan oleh M. Quraish Shihab, sebenarnya al-Qur'an lebih memihak kaum perempuan daripada kaum laki-laki. Lakilaki membutuhkan istri, tetapi ia yang harus membelanjainya. Perempuan pun membutuhkan suami, tetapi ia tidak wajib membelanjainya, bahkan dia yang harus dicukupi kebutuhannya. Sehingga

33 M. Quraish Shihab, Tafsir al-Misbah: Pesan, kesan dan keserasian Al-Qur'an, volume. 2 (Jakarta: Lentera Hati, 2000), 344 pembagian waris yang terlihat lebih banyak untuk laki-laki ternyata pada hakikatnya harta tersebut untuk istrinya pula. Jika seorang laki-laki tidak wajib membelanjainya, maka setengah dari yang seharusnya ia terima itu dapat mencukupinya. Di sisi lain, bagian perempuan yang satu itu sebenarnya cukup untuk dirinya, sebagaimana kecukupan satu bagian untuk laki-laki apabila ia tidak menikah. Tetapi jika perempuan menikah, maka keperluan hidupnya ditanggung oleh suami. Bagian laki-laki yang telah menikah tentunya akan habis dan tidak utuh karena dua bagian yang dimilikinya harus dibagi dua, sedangkan satu bagian yang dimiliki perempuan akan menjadi utuh karena tidak digunakan sama sekali. Dengan demikian keterpihakan Allah kepada perempuan lebih berat dari pada keterpihakannya kepada lakilaki dalam masalah pembagian warisan ${ }^{34}$.

Asghar Ali Engineer seorang feminis muslim India, sepakat dengan apa yang dikemukakan oleh para mufassir di atas, terkait hikmah kenapa Allah, Swt., memberikan bagian lebih besar daripada perempuan dalam hal waris. Bagi Asghar, kewajiban laki-laki dalam memberikan nafkah kepada istri dan keluarga, serta kewajiban laki-laki dalam memberikan mahar istrinya yang terkadang menuntutnya dengan jumlah yang banyak. Melihat realitas tersebut, bisa jadi bagian yang akan diterima seorang perempuan jauh lebih banyak dibandingkan laki. Dengan demikian, terkait persoalan waris harus dilihat dalam perspektif yang tepat dengan mempertimbangkan masa kini dan yang akan datang ${ }^{35}$.

Adapun yang dikritik oleh Asghar sendiri adalah penafsiran yang menjadikan ketentuan waris yang diterima perempuan sebagai alasan argumentasi dalam menganggap perempuan kebih rendah dibandingkan laki-laki. Menurutnya, alasan

Misbah...352

34 M. Quraish Shihab, Tafsir alPerempuan, terj. Agus Nuryanto, (Yogyakarta: LkiS, 2007), 100. 
tersebut tidaklah pas dan keliru, karena persoalan waris adalah termasuk dalam kategori ekonomi, sedangkan kesetaraan laki-laki dan perempuan termasuk dalam kategori moral ${ }^{36}$.

\section{DAFTAR PUSTAKA}

Abduh, Muhammad. Tafsīr al-Qur'ān alHakìm al-Syahīr bi Tafsīr alManār. Beirut: Dar al-Fikr, Tt.

Ali Engineer, Asghar. Pembebasan Perempuan. Terj. Agus Nuryanto. Yogyakarta: LkiS, 2007.

Amin Suma, Muhammad. Hukum Keluarga Islam di Dunia Islam. Jakarta: Raja Grafindo Persada, 2004.

Ar-Razi, Fakhruddin. Tafsīr al-Kabìr, Beirut: Dār al-Fikr, 1995.

Ash-Shabuni, Ali. Kitab Ilmu Waris: Mengupas Persoalan Waris Sesuai al-Qur'an dan Sunnah. Penerjemah: M. Syauqi Mubarak. Jakarta: Turos Pustaka, 2019.

Aț-Ṭabari, Ibn Jarir. Jāmi' al-Bayān fì Tafsīr al-Qur'ān. Beirut: Dār al-Fikr, Tt.

Bakhtiar, "Peranan Asbab Al-Nuzul dalam Penemuan Hukum". (Jurnal Imam Bonjol: Kajian Ilmu Informasi dan Perpustakaan, 2018.

Ikbal, Muhammad. "Hijab Dalam Kewarisan". At-Tafkir, 2018.

Ismail, Nurjannah. Perempuan Dalam Pasungan. Yogyakarta: LkiS, 2003.

Manan, Abdul. Aneka Masalah Hukum Perdata Islam di Indonesia. Jakarta: Kencana, 2006.

Maringo. "Pembagian Warisan Antara LakiLaki Dan Perempuan". Skripis: Universitas Islam Negeri Jakarta, 2017.

Moqsith Ghazali, Abdul. "Hukum Waris dalam Suatu Konteks".http://wahidinstitute.org /v1/Opini/Detail/?id=291/hl=id/H
ukum_Waris_Dalam_Suatu_Kont

eks.

Nizhan, Abu. Mutiara Shahih Asbabun Nuzul. Bandung: Salamadani, 2011.

Nuraeni, Neni. "Tafsir Ayat Ahkâm Gender (Kajian Tentang Bagian Hak Waris Dan Kepemimpinan Perempuan)". Asy-Syari'ah, 2014.

Nurdin Marjuni, Kamaluddin. Kamus Syawarifiyyah: Kamus Modern Sinonim Arab- Indonesia. Ciputat: Ciputat Press Group, 2009.

Parman, Ali. Kewarisan Dalam Al-Qur'an: Suatu Kajian Dengan Pendekatan Tafsir Tematik. Jakarta: PT Raja Grafindo Persada, 1995.

Rafiq, Ahmad. Fiqh Mawaris, Cet. 4. Jakarta: PT. Raja Grafindo Persada, 2002.

Riḍā, Rasyīd. Tafsīr al-Manār. Kairo: Dar al-Manār, Tt.

Rifenta, Fadlih. "Konsep Adil Dalam Hukum Waris Islam". Ijtihad: Jurnal Hukum dan Ekonomi Islam, 2019.

Saeed, Abdullah. Al-Qur'an Abad 21, penerjemah: Ervan Nurtawab. Bandung: Mizan, 2016.

Sahabuddin. Ensiklopedi Al-Quran: Kajian Kosakata. Jakarta: Lentera hati, 2007.

Shihab, M. Quraish. Tafsir al-Misbah: Pesan, kesan dan keserasian AlQur'an. Jakarta: Lentera Hati, 2000.

Sirin, Khaeron. "Analisis Pendekatan Teks dan Konteks dalam Penentuan Pembagian Waris Islam". AHKAM: Jurnal Ilmu Syariah, 2013.

Suparman, Eman. Hukum Waris Indonesia dalam Perspektif Islam, Adat dan $B W$, Cet. 5. Bandung: Refika Aditama, 2018. 